\title{
Assessing the long-term sustainability of the groundwater resources in the Bacchiglione basin (Veneto, Italy) with the Mann-Kendall test: suggestions for higher reliability
}

\author{
Valutazione della sostenibilità a lungo termine della risorsa idrica sotterranea nel bacino del \\ Bacchiglione (Veneto, Italia) con il test di Mann-Kendall: suggerimenti per una maggiore \\ affidabilità
}

Mara Meggiorin, Giulia Passadore, Silvia Bertoldo, Andrea Sottani, Andrea Rinaldo

\begin{abstract}
Riassunto: Il sistema acquifero all'interno del bacino del Bacchiglione (Veneto, IT) è di notevole importanza sociale, economica ed ecologica ma, circa la sostenibilità del suo utilizzo, vi sono risultati discordanti tra i precedenti studi. Questo studio indaga quindi la sostenibilità quantitativa a lungo termine di tale sistema idrico sotterraneo applicando una metodologia statistica che può essere utilizzata in studi similari. In particolare, le serie temporali disponibili vengono analizzate con i test di MannKendall e di Sen's slope, due analisi robuste e già ampiamente utilizzate negli studi ambientali. L'analisi è condotta su un dataset ampio ed eterogeneo che raccoglie serie temporali orarie del livello delle acque sotterranee in 79 punti di controllo, registrate nel periodo 2005-2019. Il test identifica trend decrescenti significativi per la maggior parte dei record disponibili, differentemente da precedenti studi sullo stato quantitativo della risorsa che coprivano il dominio qui indagato in un periodo di tempo
\end{abstract}

Keywords: seasonal Mann-Kendall test, Sen's slope estimator, sustainability, groundwater level, Bacchiglione.

Parole chiave: test stagionale Mann-Kendall, test Sen's Slope, sostenibilità, livello delle acque sotterranee, Bacchiglione.

\section{Mara MEGGIORIN 奉”}

Silvia BERTOLDO, Andrea SOTTANI

Sinergeo Srl - Vicenza, Italy

mara.meggiorin@dicea.unipd.it

sbertoldo@sinergeo.it

asottani@sinergeo.it

\section{Giulia PASSADORE}

Dipartimento di Ingegneria Civile, Edile e Ambientale, Università di Padova giulia.passadore@dicea.unipd.it

\section{Andrea RINALDO}

Dipartimento di Ingegneria Civile, Edile e Ambientale, Università di Padova Laboratory of Echohydrology (ECHO/IIE/ENAC), École Polytechnique Fédérale de Lausanne, Switzerland

andrea.rinaldo@epfl.ch

Ricevuto/Received: 15 February 2021 - Accettato/Accepted: 16 March 2021 Pubblicato online/Published online: 30 March 2021

This is an open access article under the CC BY-NC-ND license: http://creativecommons.org/licenses/by-nc-nd/4.0

(C) Associazione Acque Sotterranee 2021 leggermente diverso: 2000-2014. Il presente studio investiga le ragioni di tale divergenza nelle risultanze concentrandosi sulla sensibilità del metodo rispetto al periodo di tempo considerato. Dopo aver effettuato un'analisi di Fourier sulla serie temporale più lunga disponibile, per la valutazione dello stato quantitativo del corpo idrico questo lavoro suggerisce di applicare il test di Mann-Kendall a serie temporali più lunghe di 20 anni, altrimenti affette dalle lunghe periodicità interannuali del ciclo idrologico. Un'ulteriore analisi di due serie temporali mensili della durata di 60 anni, riferite al periodo tra 1960 e il 2020, suggerisce la sostenibilità dell'attuale utilizzo della risorsa idrica sotterranea anche se il sistema nel passato è stato di fatto depauperato. I risultati dimostrano quindi che è possibile ottenere risultati più affidabili e conclusioni significative sulla sostenibilità a lungo termine del sistema idrico sotterraneo

Abstract: The social, economic, and ecological importance of the aquifer system within the Bacchiglione basin (Veneto, IT) is noteworthy, and there is considerable disagreement among previous studies over its sustainable use. Investigating the long-term quantitative sustainability of the groundwater system, this study presents a statistical methodology that can be applied to similar cases. Using a combination of robust and widely used techniques, we apply the seasonal Mann-Kendall test and the Sen's slope estimator to the recorded groundwater level timeseries. The analysis is carried out on a large and heterogeneous proprietary dataset gathering hourly groundwater level timeseries at 79 control points, acquired during the period 2005-2019. The test identifies significant decreasing trends for most of the available records, unlike previous studies on the quantitative status of the same resource which covered the domain investigated here for a slightly different period: 2000-2014. The present study questions the reason for such diverging results by focusing on the method's accuracy. After carrying out a Fourier analysis on the longest available timeseries, for studies of groundwater status assessment this work suggests applying the Mann-Kendall test to timeseries longer than 20 years (because otherwise the analysis would be affected by interannual periodicities of the water cycle). A further analysis of two 60-year-long monthly timeseries between 1960 and 2020 supports the actual sustainable use of the groundwater resource, the past deployment of the groundwater resources notwithstanding. Results thus prove more reliable, and meaningful inferences on the longterm sustainability of the groundwater system are possible. 


\section{Introduction}

In the past, groundwater resources played a major role in economic and human development worldwide and now numerous aquifer systems have begun to show the effects of overexploitation or pollution events. One example is the central area of the Veneto Region, which has always been characterized by an abundance of groundwater resources: the drinking water supply system is mainly supplied by groundwater and, owing to this abundance of good-quality water, both industrial and agricultural activities have developed in this area with high demands for water. Due to the importance of this aquifer system, many studies have investigated it extensively due to a concern about the possible overexploitation of the resource coupled with the climate change affecting the local water balance. Between those studies, Passadore et al. (2012) notices a lowering of the water table, while ARPAV (2016) observes a rise in the monitored groundwater level.

Following the definition of the Italian law (Legislative Decree no. 30 of 16.03.2009), the assessment of the quantitative status of a groundwater system is based on an analysis of the groundwater level. Specifically, as explained and applied in ARPAV (2016), the trend in the groundwater level over time, showing aquifers storage and emptying, is an effective indicator of the exploitation sustainability of groundwater systems. Anthropogenic and climatic effects on the water balance are not differentiated; the quantitative status of the groundwater resource is assessed by looking at the overall depletion or stability of the resource volume. Thus, if the evaluated trend for a specific groundwater system is positive or stationary, the quantitative status of the water body is assessed as good. Following this line, ARPAV (2016) observes upward timeseries trends and assesses the groundwater system as having a good quantitative status, while Passadore et al. (2012) notices downward trends.

Due to such opposite results, this study assesses the quantitative status of the groundwater resource by detecting trends in the groundwater level at several control points within the Bacchiglione basin. The Mann-Kendall (MK) test (Mann 1945; Kendall 1948) and the Sen's slope estimator (Sen 1968) are used to evaluate the significance and magnitude of the trends. Such a method combination is widely used in many environmental fields, as it is often interesting to detect any possible statistically significant increasing or decreasing trends as a first indicator of human or climate change effects. Trend testing aims to determine in statistical terms if a random variable has generally increasing or decreasing values (Helsel and Hirsch 2002). Two main trend tests exist: parametric tests, which require independent and normally distributed data, and non-parametric tests, which simply need independent data. Often the choice goes to the MannKendall test for its simplicity and robustness. Indeed, it can be applied even in the presence of missing values or measures below the detection limit, which is quite common in environmental issues (Gavrilov et al. 2016). Therefore, it has been largely used for analysing trends in several climatologic parameters: from most common analyses of temperature and precipitations (Gan 1995; Wibig and Glowicki 2002; Mondal et al. 2012), to most peculiar studies on number of wet and dry months (Zhang et al. 2009), evapotranspiration (Tabari et al. 2011; Shadmani et al. 2012), atmospheric deposition (Drápela and Drápelová 2011; Waldner et al. 2014), hail (Gavrilov et al. 2010) and aridity (Some'e et al. 2013; Hrnjak et al. 2014). Specifically on hydrological timeseries, many studies tested stream flows all over the world (Douglas et al. 2000; Kahya and Kalayc1 2004; Svensson et al. 2005), few focused on groundwater levels (Panda et al. 2007; Polemio and Casarano 2008; Du Bui et al. 2012; Tabari et al. 2012; Vousoughi et al. 2013; Patle et al. 2015; Ribeiro et al. 2015) and still less on groundwater quality (Ribeiro and Macedo 1995; Daughney and Reeves 2006; Aguilar et al. 2007; Wahlin and Grimvall 2010).

Other than the sustainability assessment of the groundwater system, this study highlights a critical aspect of the application of the Mann-Kendall test and the Sen's slope estimator that is linked to the period analysed. Indeed, the results of the dataset used here differ depending on the period considered. Moreover, the results are opposite to those of ARPAV (2016), which carried out the same analysis in the Veneto Region, including a few timeseries recorded at control points within the Bacchiglione basin. Thus, this study aims to better understand the methodological approach, with the intention to use the method properly and deliver more reliable results. First, the Mann-Kendall test and the Sen's slope estimator are applied to the available dataset to evaluate groundwater level trends between 2005 and 2019, and to test the applicability of the trend testing procedure for groundwater level datasets that are usually characterised by missing data and timeseries of different lengths. Then, diverging results are further investigated because the results arise a critical aspect of the method in assessing long-term groundwater trends, and finally, a few clear suggestions are presented for achieving more reliable conclusions from assessing the sustainable exploitation of groundwater systems that respond slowly to human and hydraulic stresses.

\section{Study area}

The trend detection analysis is applied to several control points that continuously measure the groundwater level within the basin of the Bacchiglione river located in the Veneto plain and covering the alluvial plain to the north of Vicenza, the study domain is shown in Figure 1. Abundant groundwater is present here, owing to two main factors: the particularly permeable subsoil and the strong connections between rivers and groundwater that ensure the recharging of the aquifer system.

Geologically speaking, in the upper plain, the Piedmont area has a continuous, undifferentiated gravelled subsoil because of the overlapping alluvial fans. Such overlapping is due to the instability of rivers and their wide movement in past centuries. Going downstream towards South-East, the course material thickness decreases gradually in the middle 


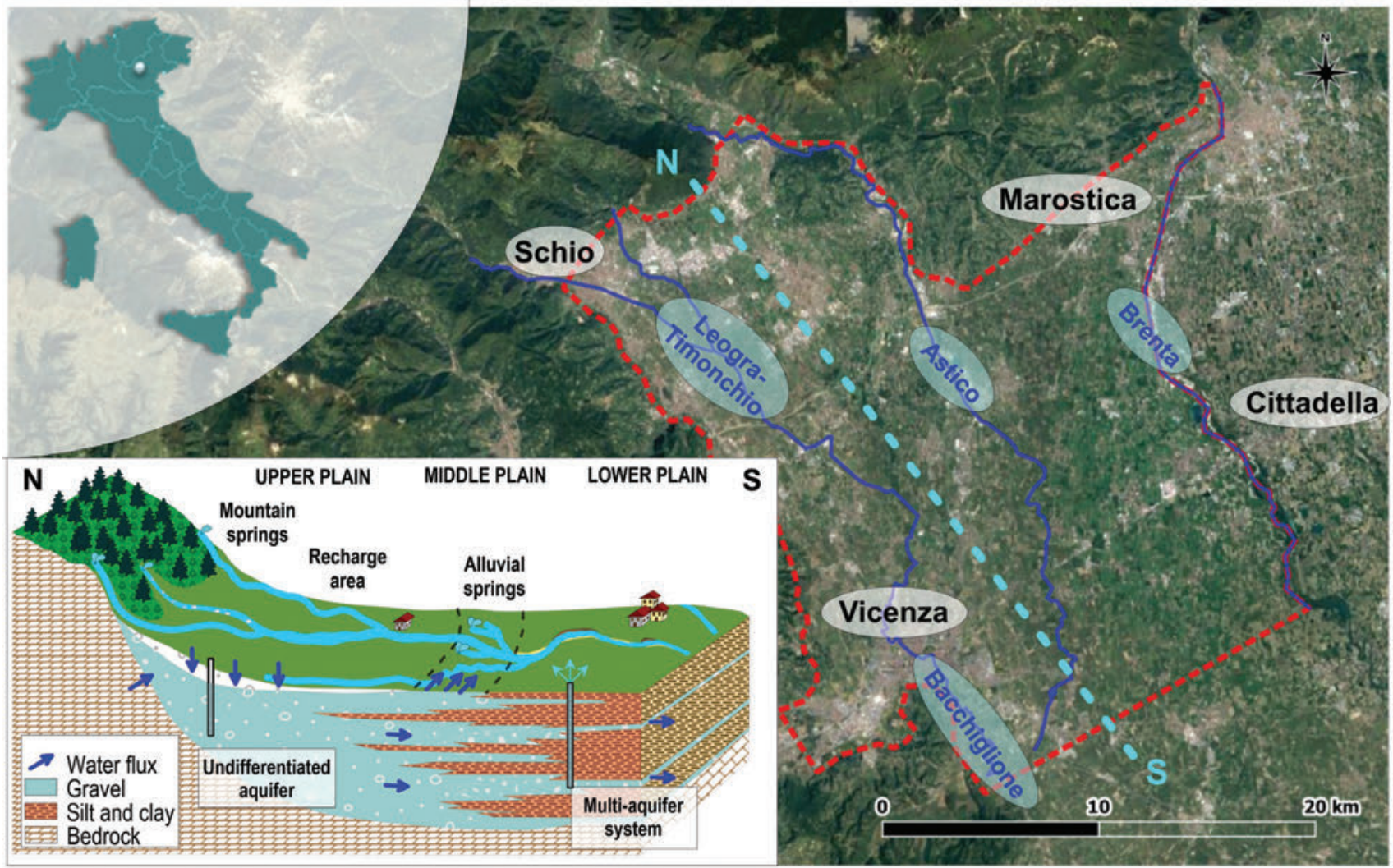

Fig. 1 - Plan view of the study area with main cities, main river tracks and the reference geological scheme of the Veneto plain.

Fig. 1 - Vista in pianta dell'area di studio con riportate le città principali, i fiumi più importanti nel territorio e lo schema geologico di riferimento della pianura veneta.

plain to the point where the coarse layers vanish into fine materials in the lower plain (Dal Prà et al. 1976, 1977). At this point, gravelled layers of alluvial fans are rare, relatively thin, and deep. This Quaternary formation lies on a bedrock of the Tertiary age located at a depth ranging from a few meters in the upper Veneto plain to several hundred meters towards the southeast.

The hydrogeological system is connected with the local geological characteristics. Thus, in the Piedmont area, there exists a unique powerful unconfined aquifer that lies directly on the bedrock and has a water table that oscillates freely depending on periodic hydraulic dynamics. In the middle plain, the Quaternary formation is stratified, which determines the presence of a layered multi-aquifer system. Given its ease of water extraction and its protection from surface polluting events, the multi-aquifer system is the main water resource for the public supply of drinkable water in the area, mainly the 3 rd and 4th confined aquifers.

\section{Data and methods}

Owing to the instruments and proprietary databases of Sinergeo, the present study is based on a large amount of data, which is heterogeneous in time and space. Within the domain of interest, 102 monitoring points were equipped with automatic instrumentation to record the piezometric head with a sampling interval of 1 or 3 hours. However, as happens in many real case studies, the available dataset is affected by missing values and outliers. Missing data occurred because the installed sensors continuously recorded the hydraulic head, but they were installed during different periods, thus the available timeseries have a variable length ranging from 3 months to almost 14 years. In addition, timeseries can have gaps due to the breakdown of sensors or due to particularly dry periods for which the specific sensor is not located deep enough or the well depth is insufficient. Moreover, there may be some outliers due to sensor malfunctions or to the pumping effect of nearby wells, and these outliers must be removed for the purpose of this study. Outliers are usually defined as values below the 10th and above the 90th percentiles, which are easily identifiable in timeseries data depicted in a boxplot graph. However, some outliers could be representative of hydrologically relevant peaks, therefore they are meaningful values. For this reason, series with identified outliers in the boxplot are checked by displaying values against time to classify outliers as natural phenomena or measurement errors. To carry out a meaningful analysis, records were then selected that had at least two years of data and less than $50 \%$ of values missing, thus 79 sensors were selected (listed in Table 1).

As a trend test, this study applies the widely used MK test, a non-parametric test assuming stable, independent, and random timeseries with equal probability distributions. Unlike parametric trend tests, there is no normality assumption, and the MK test is less affected by outliers or missing data than the linear regression method (Ribeiro et al. 2015). Yue et al. (2002) found that the test becomes more powerful the greater the absolute magnitude of the trend and 
Tab. 1 - List of the sensors considered for the timeseries analysis with the Mann-Kendall test and the Sen's slope estimator: recorded period, timeseries length (years), percentage of missing data $(\%)$, intercepted aquifer type, depth of the piezometer $(\mathrm{m})$, average depth of the water table $(\mathrm{m})$.

Tab. 1 - Elenco dei sensori utilizzati per l'analisi delle serie storiche con i test Mann-Kendall e Sen's Slope: periodo monitorato, lunghezza della serie [anni], percentuale di dati mancanti [\%], acquifero intercettato, profondità del piezometro [m], profondità media del livello di falda [m].

\begin{tabular}{|c|c|c|c|c|c|c|}
\hline ID & Recorded period & Series length & $\%$ Missing data & Aquifer type & $\begin{array}{c}\text { Piezometer } \\
\text { depth }\end{array}$ & $\begin{array}{l}\text { Average depth of } \\
\text { the water table }\end{array}$ \\
\hline 2 & apr $15-$ mar 18 & 2.9 & 1.4 & unconfined & 35.0 & 18.6 \\
\hline 25 & apr 06 - oct 17 & 11.5 & 3.8 & unconfined & 29.0 & 20.3 \\
\hline 26 & jul 06 - oct 18 & 12.2 & 7.9 & unconfined & 123.0 & 95.9 \\
\hline 27 & jun 07 - nov 18 & 11.5 & 15.0 & unconfined & 30.2 & 25.5 \\
\hline 28 & jul 06 - feb 18 & 11.6 & 0.0 & unconfined & 6.0 & 4.8 \\
\hline 29 & aug $06-\operatorname{dec} 18$ & 12.4 & 18.5 & unconfined & 15.8 & 14.4 \\
\hline 30 & jan $08-\operatorname{dec} 18$ & 11.0 & 14.8 & unconfined & 29.4 & 27.1 \\
\hline 31 & jul 06 - jan 19 & 12.5 & 0.0 & unconfined & 11.5 & 8.0 \\
\hline 32 & jul 07 - dec 18 & 11.5 & 4.7 & unconfined & 21.2 & 16.5 \\
\hline 33 & may 05 - dec 18 & 13.6 & 4.2 & unconfined & 104.0 & 74.6 \\
\hline 34 & jul 06 - nov 18 & 12.4 & 0.0 & unconfined & 6.0 & 2.0 \\
\hline 35 & jul 06 - nov 18 & 12.4 & 2.5 & unconfined & 22.0 & 14.2 \\
\hline 36 & mar 09 - jul 18 & 9.3 & 0.0 & unconfined & 22.8 & 10.7 \\
\hline 37 & jul 06 - dec 18 & 12.4 & 0.1 & unconfined & 27.0 & 24.3 \\
\hline 38 & jul 06 - nov 18 & 12.4 & 10.4 & unconfined & 33.6 & 28.8 \\
\hline 39 & aug $07-\operatorname{dec} 18$ & 11.4 & 15.1 & unconfined & 34.8 & 29.8 \\
\hline 40 & jul $06-\operatorname{dec} 18$ & 12.4 & 2.8 & unconfined & 8.5 & 5.9 \\
\hline 41 & nov 07 - dec 18 & 11.1 & 25.2 & unconfined & 65.9 & 46.4 \\
\hline 42 & apr 07 - aug 18 & 11.3 & 5.0 & unconfined & 17.3 & 12.1 \\
\hline 43 & apr $10-$ jan 19 & 8.7 & 1.2 & unconfined & - & 27.1 \\
\hline 44 & apr 10 - nov 18 & 8.6 & 2.2 & unconfined & 66.5 & 34.8 \\
\hline 45 & oct $15-$ nov 18 & 3.0 & 0.0 & unconfined & 18.0 & 5.9 \\
\hline 46 & mar $12-$ nov 18 & 6.7 & 4.0 & unconfined & 45.5 & 26.4 \\
\hline 53 & may 05 - aug 13 & 8.3 & 3.6 & confined & 41.5 & 3.3 \\
\hline 54 & jun 05 - dec 18 & 13.6 & 18.9 & confined & 60.0 & 2.5 \\
\hline 55 & jun 05 - dec 18 & 13.5 & 20.6 & confined & 101.0 & 1.4 \\
\hline 56 & jun 05 - dec 17 & 12.5 & 24.0 & confined & 96.5 & 3.2 \\
\hline 57 & apr $05-\operatorname{dec} 18$ & 13.7 & 0.1 & unconfined & 9.7 & 2.0 \\
\hline 58 & may 08 - feb 19 & 10.8 & 10.7 & unconfined & 7.5 & 2.8 \\
\hline 59 & may 08 - feb 19 & 10.8 & 29.9 & unconfined & 6.4 & 1.9 \\
\hline 80 & nov $13-\operatorname{dec} 18$ & 5.1 & 1.2 & unconfined & 55.0 & 38.6 \\
\hline 81 & nov 13 - dec 18 & 5.1 & 0.0 & unconfined & 60.0 & 50.0 \\
\hline 82 & oct 11 - nov 18 & 7.1 & 0.2 & unconfined & 65.0 & 53.0 \\
\hline 83 & oct $11-$ nov 16 & 5.1 & 1.8 & confined & - & 25.9 \\
\hline 91 & sep 11 - nov 18 & 7.2 & 0.6 & unconfined & 26.0 & 2.9 \\
\hline 92 & oct $11-$ nov 18 & 7.2 & 22.7 & unconfined & - & 5.4 \\
\hline 94 & sep 11 - nov 18 & 7.2 & 13.0 & unconfined & 26.5 & 2.3 \\
\hline 95 & sep 11 - feb 19 & 7.4 & 12.6 & unconfined & 34.0 & 4.6 \\
\hline 103 & apr $10-\operatorname{dec} 18$ & 8.7 & 0.2 & unconfined & 5.6 & 1.8 \\
\hline 104 & apr 10 - mar 17 & 6.9 & 2.1 & confined & - & 2.7 \\
\hline
\end{tabular}


Tab. 1 - List of the sensors considered for the timeseries analysis with the Mann-Kendall test and the Sen's slope estimator: recorded period, timeseries length (years), percentage of missing data (\%), intercepted aquifer type, depth of the piezometer $(\mathrm{m})$, average depth of the water table $(\mathrm{m})$.

Tab. 1 - Elenco dei sensori utilizzati per l'analisi delle serie storiche con i test Mann-Kendall e Sen's Slope: periodo monitorato, lunghezza della serie [anni], percentuale di dati mancanti [\%], acquifero intercettato, profondità del piezometro [m], profondità media del livello di falda [m].

\begin{tabular}{|c|c|c|c|c|c|c|}
\hline ID & Recorded period & Series length & $\%$ Missing data & Aquifer type & $\begin{array}{l}\text { Piezometer } \\
\text { depth }\end{array}$ & $\begin{array}{l}\text { Average depth of } \\
\text { the water table }\end{array}$ \\
\hline 110 & dec $10-\operatorname{dec} 18$ & 8.0 & 10.2 & confined & 48.0 & 6.7 \\
\hline 111 & dec $10-\operatorname{dec} 18$ & 8.0 & 3.3 & confined & 50.0 & 3.6 \\
\hline 112 & dec $10-\operatorname{dec} 18$ & 7.9 & 2.1 & confined & 48.0 & 6.4 \\
\hline 113 & apr $15-\operatorname{dec} 18$ & 3.7 & 12.0 & confined & 10.0 & 6.2 \\
\hline 114 & may $15-\operatorname{dec} 18$ & 3.6 & 33.4 & confined & 42.5 & 0.4 \\
\hline 125 & oct 11 - feb 19 & 7.4 & 0.0 & unconfined & 35.0 & 22.5 \\
\hline 126 & oct 11 - feb 19 & 7.4 & 0.0 & unconfined & 35.0 & 23.8 \\
\hline 128 & nov 11 - feb 19 & 7.2 & 2.2 & confined & 8.0 & 2.0 \\
\hline 129 & feb 12 - feb 19 & 7.0 & 4.6 & unconfined & 12.0 & 8.5 \\
\hline 130 & feb 12 - feb 19 & 7.0 & 0.0 & unconfined & 26.0 & 12.7 \\
\hline 131 & feb 12 - feb 19 & 7.0 & 0.0 & unconfined & 12.0 & 4.3 \\
\hline 133 & apr $15-\operatorname{dec} 18$ & 3.7 & 15.2 & unconfined & 6.2 & 2.5 \\
\hline 134 & oct $11-\operatorname{dec} 18$ & 7.2 & 11.8 & unconfined & 6.0 & 4.4 \\
\hline 135 & oct $11-\operatorname{dec} 18$ & 7.2 & 0.0 & confined & 6.0 & 2.5 \\
\hline 136 & oct $11-\operatorname{dec} 18$ & 7.2 & 0.0 & confined & 6.0 & 3.9 \\
\hline 139 & mar $07-$ nov 18 & 11.7 & 0.0 & unconfined & 30.0 & 16.4 \\
\hline 140 & mar $07-$ nov 18 & 11.7 & 2.5 & unconfined & 25.0 & 15.7 \\
\hline 141 & mar 07 - nov 18 & 11.7 & 0.0 & unconfined & 20.0 & 6.4 \\
\hline 142 & mar $07-$ nov 18 & 11.7 & 0.0 & unconfined & 22.0 & 9.5 \\
\hline 143 & may 08 - nov 18 & 10.5 & 0.0 & unconfined & 20.0 & 8.2 \\
\hline 144 & may 08 - nov 18 & 10.5 & 0.0 & unconfined & 20.0 & 6.7 \\
\hline 145 & may 08 - nov 18 & 10.5 & 0.8 & unconfined & 20.0 & 5.9 \\
\hline 146 & may 08 - nov 18 & 10.5 & 0.0 & unconfined & 18.0 & 6.7 \\
\hline 147 & may 08 - nov 18 & 10.5 & 0.0 & unconfined & 20.0 & 7.6 \\
\hline 148 & may 08 - nov 18 & 10.5 & 0.0 & unconfined & 14.0 & 3.4 \\
\hline 149 & may 08 - nov 18 & 10.5 & 1.1 & unconfined & 12.0 & 2.0 \\
\hline 151 & mar 07 - nov 18 & 11.7 & 0.0 & unconfined & 25.0 & 16.4 \\
\hline 153 & oct 09 - oct 18 & 9.0 & 0.0 & unconfined & 6.0 & 2.1 \\
\hline 159 & jul 13 - jul 18 & 5.0 & 0.0 & unconfined & 60.0 & 49.4 \\
\hline 168 & jan $16-j a n 19$ & 3.0 & 0.0 & unconfined & 30.0 & 19.6 \\
\hline 169 & sep 09 - jan 19 & 9.4 & 2.1 & unconfined & 35.0 & 23.0 \\
\hline 170 & mar 13 - jan 19 & 5.9 & 9.3 & unconfined & 20.0 & 16.8 \\
\hline 190 & jun 14 - nov 18 & 4.4 & 9.9 & unconfined & 25.0 & 16.7 \\
\hline 194 & jun 14 - nov 18 & 4.4 & 35.1 & unconfined & 15.0 & 9.7 \\
\hline 198 & apr $15-$ nov 18 & 3.6 & 1.0 & unconfined & 40.0 & 34.6 \\
\hline 200 & nov 14 - feb 19 & 4.2 & 13.5 & unconfined & 40.0 & 26.7 \\
\hline 203 & mar 15 - feb 19 & 3.9 & 0.0 & unconfined & 37.0 & 25.8 \\
\hline 204 & oct $15-$ mar 18 & 2.5 & 0.0 & unconfined & 14.0 & 12.0 \\
\hline 206 & $\operatorname{mar} 15-\operatorname{mar} 19$ & 3.9 & 12.4 & unconfined & 24.6 & 14.3 \\
\hline
\end{tabular}


as the sample size increases, while its power decreases if the amount of variation increases. Moreover, potential scaling effects could be present in identifying timeseries trends, as found in some runoff studies (Koutsoyiannis 2003; Hamed 2008). The specific effect is not considered here, but scaling is accounted by a modified MK test, which can eliminate potential contradictions related to local or regional scales.

The analysis consists of using Kendall's significance test for a time variable to detect the trend. In this test, two hypotheses are tested for each timeseries: the null hypothesis $\left(\mathrm{H}_{0}\right)$ of no trend and the alternative hypothesis $\left(\mathrm{H}_{\mathrm{a}}\right)$ of a significant trend. As for all statistical hypothesis tests, $H_{a}$ is accepted if there is an unlikely realization of $\mathrm{H}_{0}$ according to a predefined threshold probability, the significance level $\alpha$. Therefore, if the probability $p$ is lower than the chosen $\alpha$, the null hypothesis of no trend should be rejected and the alternative hypothesis accepted, otherwise the null hypothesis cannot be rejected.

Specifically, the Kendall's $S$ statistic is used to understand whether a variable $Y$ tends to monotonically increase or decrease over time $t$. Precisely, for a timeseries $(Y ; t)$ composed by $n$ time steps, for instants $i>j$, all values pairs $y_{i}, y_{j}$ are inspected and classified into $y_{i}>y_{j}$ or $y_{i}<y_{j}$. Then, couples of the two classes are counted: $P$ is the number of the former class, $M$ of the latter class. The $S$ statistic is defined as their difference $P-M$ and it is asymptotically normal (Kendall 1948).

As explained and applied in Ribeiro et al. (2015), groundwater levels could show different seasonal patterns depending on specific trends of balance factors affecting the analysed timeseries such as rain, snow or evapotranspiration. Therefore, the seasonal MK test is used by separately computing the $S$ statistic for each considered season. This study aims to detect monthly trends, thus the $S$ statistic is estimated for each of the $p$ months and then the overall statistic $S_{\mathrm{k}}$ is defined as

$$
S_{k}=\sum_{i=1}^{p=12} S_{i}
$$

As longer the timeseries is as better the $S_{k}$ distribution can be approximated to a normal distribution and therefore it can be standardized as:

$$
Z_{K}=\left\{\begin{array}{cl}
\frac{S_{k}-1}{\sigma_{k}} & \text { if } S_{k}>0 \\
0 & \text { if } S_{k}=0 \\
\frac{S_{k}+1}{\sigma_{k}} & \text { if } S_{k}<0
\end{array}\right.
$$

where $\sigma_{\mathrm{k}}$ is the standard deviation of $S_{k}$ and it is calculated as

$$
\sigma_{k}=\sqrt{\sum_{i=1}^{p} \frac{n_{i}}{18}\left(n_{i}-1\right)\left(2 n_{i}+5\right)}
$$

where $n_{i}$ is the number of values in season $i$ and $p$ is the number of seasons, i.e. 12 months for this case study. The so defined statistic $Z_{k}$ is then compared to the threshold $Z_{\text {crit }}$ defined as the value of the standard normal distribution corresponding to an exceedance probability of $\alpha / 2, Z_{(1-\alpha / 2)}$. The null hypothesis is rejected if $\left|Z_{k}\right|>Z_{(1-\alpha / 2)}$, thus a significant trend in the timeseries is detected, otherwise the null hypothesis of no trend cannot be rejected.

Sen's slope estimator (Sen 1968) is a usual additional analysis to the MK test because it estimates the trend slope for the variable $Y$ over time $t$ (Drápela and Drápelová 2011; Mondal et al. 2012; Gocic and Trajkovic 2013; Ribeiro et al. 2015; Rahman and Dawood 2017). For each month $k$, in a sample of $n_{k}$ pairs of data $y_{i}, y_{j}$ with $1 \leq j \leq i \leq n_{k}$, the slope estimate is the median of $D_{i j k}$ :

$$
D_{i j k}=\frac{y_{i k}-y_{j k}}{i-j} \text { for } \mathrm{k}=1, \ldots, 12
$$

The estimator is robust against outliers and serial correlation effects are unlikely because, in this study, $D_{i j k}$ are computed on values that are 12 months apart (Hirsch et al. 1982).

\section{Results}

Passadore et al. (2012) notices clearly lowering water tables while ARPAV (2016) observes upward trends. These different results for the same aquifer system cast doubt on the sustainability of the actual unplanned groundwater resource exploitation within the Bacchiglione basin with the climate change affecting the local water balance. As a further sustainability verification of the system, the seasonal MannKendall test is applied to the available timeseries dataset to identify statistically significant trends, and the Sen's slope estimator is used to assess their magnitude. The timeseries used are monthly medians of available recordings, and the selected significance level is 0.1 .

As already highlighted, the main issue of the analysed dataset by the present study is the different lengths of the available timeseries, ranging from 2 to 14 years. As a homogenizing technique for this analysis, at first two different overall trend analyses were carried out using time periods with enough recording sensors: three years during 2015-2017 and 10 years during 2009-2018. In both cases, the dataset included only timeseries with less than $35 \%$ of data missing in the considered period: 77 sensors for the three-year analysis and 59 for the latter. Both periods were selected to gather the most control points, and they occur to start from a period of maximum hydraulic head and end in a dry period. Consequently, both analyses identify more than $60 \%$ of trends as significant, almost all negative, visible in Figures 2 and 3. For the ease of comparison, dataset sensors are categorized into five different sectors depending on the most likely hydraulic drivers: Leogra-Timonchio river system (LT), Astico river (A), both Leogra-Timonchio and Astico influence (LTA), Brenta river (B) and in the downstream confined system close by Vicenza (V). 

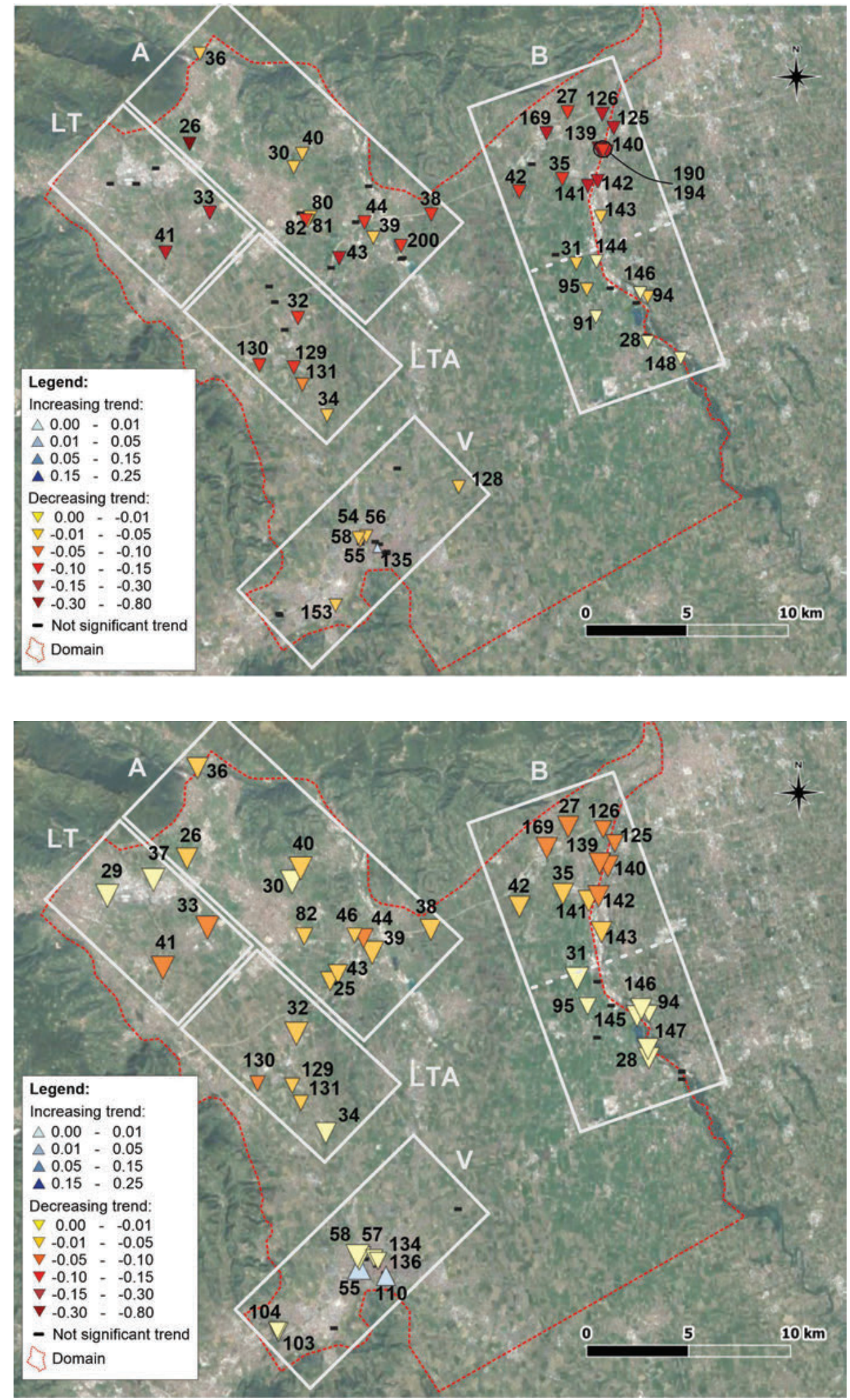

Fig. 2 - Statistically significant trends of the groundwater level timeseries on the period 2015-2017. The magnitude of the decreasing or increasing trends (symbol colour) is estimated by the Sen's slope estimator. Gray rectangles subdivide the domain into five sectors depending on main bydraulic drivers. Black numbers show sensors ID.

Fig. 2 - Trend statisticamente significativi del livello delle acque sotterranee, nel periodo 2015-2017. L'entità dei trend decrescenti o crescenti (rappresentata dalla classe di colore) è stata valutata con il test Sen's Slope. I rettangoli grigi suddividono il dominio in cinque settori a seconda dei drivers idraulici. I numeri in nero riportano gli ID dei sensori.

Fig. 3 - Statistically significant trends of the groundwater level timeseries on the period 2009-2018. The magnitude of the decreasing or increasing trends (symbol colour) is estimated by the Sen's slope estimator. Gray rectangles subdivide the domain into five sectors depending on main hydraulic drivers. Black numbers show sensors $I D$.

Fig. 3 - Trend statisticamente significativi del livello delle acque sotterranee, nel periodo 2009-2018. L'entità dei trend decrescenti o crescenti (rappresentata dalla classe di colore) è stata valutata con il test Sen's Slope. I rettangoli grigi suddividono il dominio in cinque settori a seconda dei drivers idraulici. I numeri in nero riportano gli ID dei sensori.

To avoid bias linked to the selected period, the third analysis does not define the period, and all available timeseries were analysed, even if they have different recording lengths. As a reminder of the dataset heterogeneity,
Figure 4 reports identified significant overall trends with symbol sizes dependent on the timeseries length, highlighting longer records.

Results are slightly different from previous period-defined 


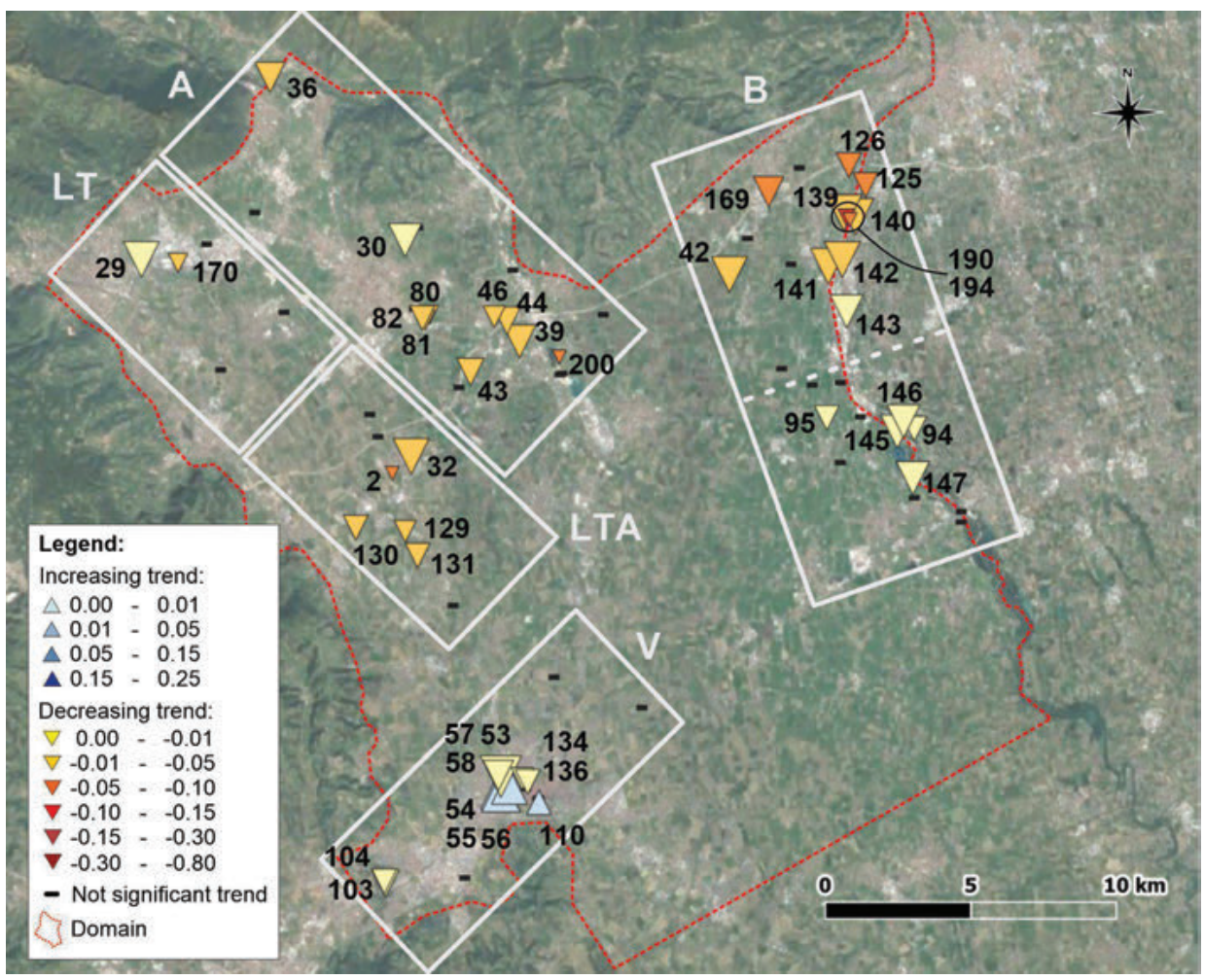

Fig. 4 - Statistically significant trends of the groundwater level timeseries, considering all available timeseries. The magnitude of the decreasing or increasing trends (symbol colour) is estimated by the Sen's slope estimator. Gray rectangles subdivide the domain into five sectors depending on hydraulic drivers. Black numbers show sensors ID.

Fig. 4 - Trend statisticamente significativi del livello delle acque sotterranee, considerando l'intero periodo disponibile. L'entità dei trend decrescenti o crescenti (rappresentata dalla classe di colore) è stata valutata con il test Sen's Slope. I rettangoli grigi suddividono il dominio in cinque settori a seconda dei drivers idraulici. I numeri in nero riportano gli ID dei sensori.

analyses: note that sensors 26 and 33 do not show significant trends for the all-inclusive analysis, but they do show a decreasing trend in the two previous analyses with 3-and 10year periods. This discrepancy is due to their recording start time, which was spring 2005. Indeed, this antecedent period between 2005 and 2009 was characterized by a generally low hydraulic head with a particularly dry period in spring and summer 2007. This low water table period clearly influences the Mann-Kendall test and the Sen's slope estimator: as an example, Figure 5 highlights the distinct estimated trends for the different periods considered, with continuous lines if they have been defined as statistically significant by the MK test or with dashed lines otherwise.

Nevertheless, even in this all-inclusive test, the majority of identified significant trends are negative. The only exceptions are the four sensors with a positive average trend slope of 3.3 $\mathrm{mm} / \mathrm{month}$ : all are in the confined system of the Vicenza area. Other shallower sensors nearby show decreasing trends instead: they mostly intercept the phreatic aquifer. There is only one (sensor 136) with a decreasing trend that intercepts
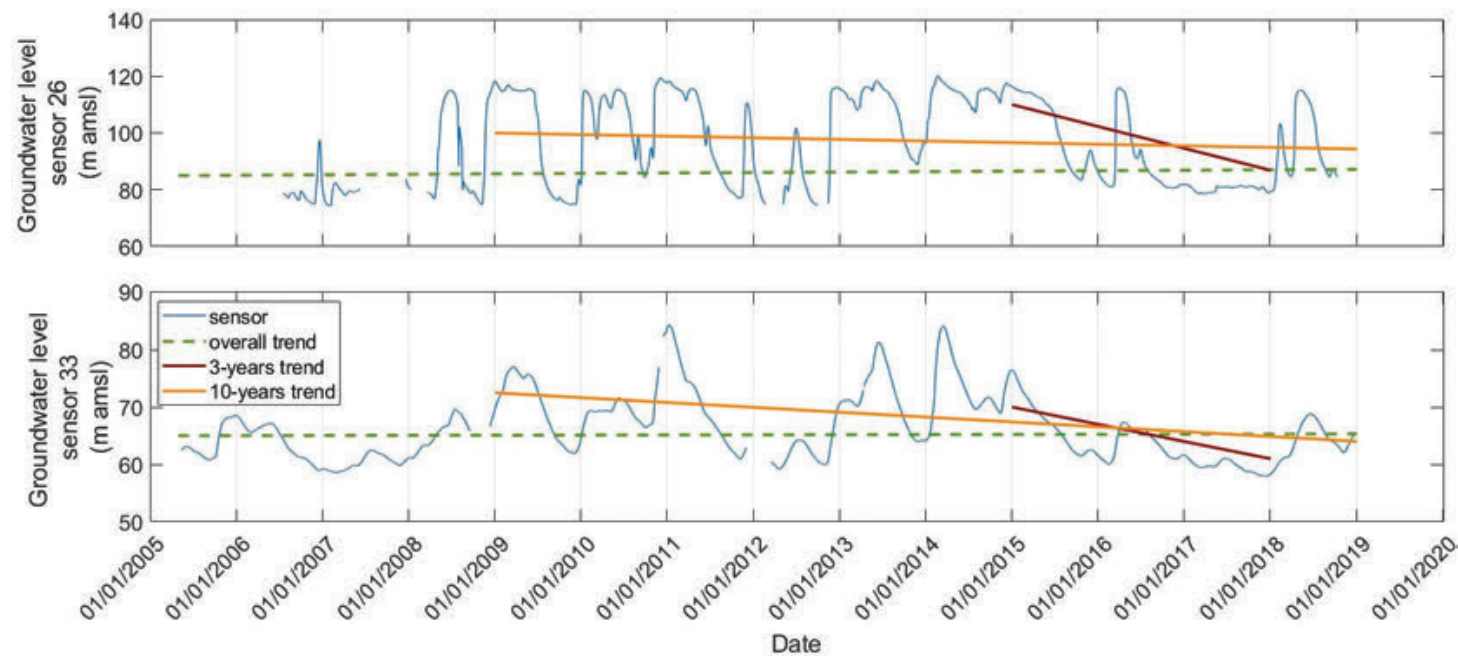

Fig. 5 - Groundwater level timeseries of sensors 26, 33 and statistically significant trends. Trends are estimated for three different time periods: all recording, 2015-2017, 20092018. Trend lines are continuous if the trend has been evaluated as significant, dashed otherwise.

Fig. 5 - Serie storiche del livello delle acque sotterranee dei sensori 26, 33 ed i loro trend. I trend delle serie storiche sono stimati per i tre differenti periodi considerati: l'intera serie disponibile, 2015-2017, 2009-2018. Le linee di tendenza sono continue se il trend è stato valutato significativo, tratteggiato altrimenti. 
Tab. 2 - Summary of the Mann-Kendall test and Sen's slope estimator for the seasonal (monthly MK), the overall, the 3-years and 10-years analyses: number of analysed sensors, identified statistically significant positive and negative trends, not significant trends, their percentages and the mean significant positive and negative slopes for the whole dataset (cm/month).

Tab. 2 - Riassunto dei risultati del test Mann-Kendall test e del Sen's slope per le analisi stagionale (MK mensile) e considerando l'intera serie storica, 3 anni e 10 anni: il numero di serie storiche analizzate, i trend valutati statisticamente positivi e negativi, trend non significativi, le loro percentuali e la pendenza media dei trend statisticamente positivi e negativi per l'intero dataset disponibile $[\mathrm{cm} / \mathrm{mese}]$.

\begin{tabular}{|l|l|l|l|c|c|c|c|c|c|}
\cline { 2 - 10 } & N. sensors & $\begin{array}{c}\text { N. pos } \\
\text { trends }\end{array}$ & $\begin{array}{c}\text { N. neg } \\
\text { trends }\end{array}$ & $\begin{array}{c}\text { N. not } \\
\text { significant } \\
\text { trends }\end{array}$ & $\begin{array}{c}\% \text { pos } \\
\text { trends }\end{array}$ & $\begin{array}{c}\% \text { neg not } \\
\text { trends }\end{array}$ & $\begin{array}{c}\text { Average pos } \\
\text { significant } \\
\text { trends }\end{array}$ & $\begin{array}{c}\text { Average } \\
\text { slopeg slope }\end{array}$ \\
\hline Jan MK & 79 & 2 & 5 & 72 & $3 \%$ & $6 \%$ & $91 \%$ & 2.49 & -2.81 \\
\hline Feb MK & 79 & 1 & 1 & 77 & $1 \%$ & $1 \%$ & $97 \%$ & 22.86 & -4.44 \\
\hline Mar MK & 79 & 2 & 2 & 75 & $3 \%$ & $3 \%$ & $95 \%$ & 1.12 & -4.41 \\
\hline Apr MK & 79 & 0 & 3 & 76 & $0 \%$ & $4 \%$ & $96 \%$ & - & -4.75 \\
\hline May MK & 79 & 2 & 3 & 74 & $3 \%$ & $4 \%$ & $94 \%$ & 1.03 & -1.28 \\
\hline Jun MK & 79 & 1 & 5 & 73 & $1 \%$ & $6 \%$ & $92 \%$ & 0.46 & -1.16 \\
\hline Jul MK & 79 & 1 & 6 & 72 & $1 \%$ & $8 \%$ & $91 \%$ & 0.40 & -1.52 \\
\hline Aug MK & 79 & 2 & 2 & 75 & $3 \%$ & $3 \%$ & $95 \%$ & 3.08 & -1.01 \\
\hline Sept MK & 79 & 4 & 3 & 72 & $5 \%$ & $4 \%$ & $91 \%$ & 0.38 & -5.59 \\
\hline Oct MK & 79 & 1 & 8 & 70 & $1 \%$ & $10 \%$ & $89 \%$ & 0.29 & -4.77 \\
\hline Nov MK & 79 & 1 & 6 & 72 & $1 \%$ & $8 \%$ & $91 \%$ & 0.42 & -6.55 \\
\hline Dec MK & 79 & 1 & 16 & 62 & $1 \%$ & $20 \%$ & $78 \%$ & 14.91 & -5.92 \\
\hline Overall MK & 79 & 4 & 41 & 34 & $5 \%$ & $52 \%$ & $43 \%$ & 0.33 & -2.82 \\
\hline MK 3years & 77 & 1 & 47 & 29 & $1 \%$ & $61 \%$ & $38 \%$ & 0.21 & -10.19 \\
\hline MK 10years & 59 & 2 & 45 & 12 & $3 \%$ & $76 \%$ & $20 \%$ & 0.15 & -2.98 \\
\hline
\end{tabular}

the first confined aquifer, but it is close to a few pumping wells, and it is probably affected by them. Negative slopes are indeed present in the confined system for the shallowest aquifer, although their magnitude is less than the decreasing trends of the upstream unconfined aquifer within the river systems of Leogra-Timonchio, Astico, and Brenta. With the shortest timeseries usually characterized by highest negative slopes removed, the average decreasing slope for the domain is $2.13 \mathrm{~cm} / \mathrm{month}$, whereas Table 2 summarizes the results for the whole dataset.

To highlight the possible trend patterns depending on balance factors with specific seasonal trends, the seasonal MK tests the trend significance for each month considering the whole timeseries available. Observing resulting trends in Table 2, Figures 6 and 7, all months show no significant trends for the majority of sensors; those sensors with seasonally significant trends vary depending on the month. A few similarities are present between the different river systems: decreasing trends in June and July for the LeograTimonchio, Astico, and Brenta sectors, and dramatically decreasing trends in December for the two latter sectors. The sector around the Brenta river is the one most visibly affected by negative trends: 16 decreasing trends in the winter month of December, while other months have between one and three identified decreasing trends.

To relate the identified trends with trends related to water balance factors within the domain, the seasonal MK analysis is also applied to the available timeseries of rainfalls and river flowrates (listed in Table 3), both 13 years long and recorded by ARPAV stations. The flowrate timeseries of the Leogra river was made available by the CIN [Centro Idrico di Novoledo, personal communication (2019)] for the monitoring station in Torrebelvicino.

They do not generally observe significant trends: precipitation sometimes shows significant seasonal trends, while rivers timeseries do show overall significant trends for the periods 2015-2017 and 2009-2018. Specifically, in the Brenta area, four rainfall timeseries have a decreasing seasonal trend between August and September, but for the groundwater timeseries, if they have a trend, it is upward. This discrepancy could be due to irrigation, which is quite a diffuse practice in this area, and which balances the precipitation deficit. The last significant rainfall seasonal trend is positive and is seen in January for the weather station in Montecchio Precalcino, likely influencing the A and LTA sectors. However, neither sectors see any significant January trend except for one decreasing trend. Precipitation trends are therefore not relatable to those of the water table. The Astico and Brenta river flowrate timeseries do present significant overall decreasing trends for the 3- and 10-year analyses, but they do not for the all-inclusive analysis. These river decreasing trends are in line with those of surrounding sensors, but they are not sufficient evidence to deduce more about their hydraulic connections. The Leogra-Timonchio river system instead has no significant trends, either seasonal or overall, which precludes any deeper insight. 
Tab. 3 - List of precipitation and river flowrates sensors considered for the analysis and summary of the Mann-Kendall test results (only analyses with identified significant trends are here reported): sensor ID, recorded period, timeseries length (years), identified statistically significant trends of the seasonal MK in January, August and September, identified statistically significant trends of the 3-year and 10-year analyses.

Tab. 3 - Elenco dei sensori di precipitazione e di portata dei fiumi utilizzati per l'analisi e sintesi dei risultati del test di Mann-Kendall (vengono qui riportate solo le analisi con trend significativi): ID del sensore, periodo registrato, durata della serie temporale [anni], trend statisticamente significativi identificati dal MK test in gennaio, agosto e settembre, trend statisticamente significativi delle analisi considerando 3 e 10 anni.

\begin{tabular}{|c|c|c|c|c|c|c|c|}
\hline ID & Available recorded period & Series length & Jan MK & Aug MK & Sept MK & MK 3 years & MK 10 years \\
\hline prec ARPAV 81 & apr $05-$ nov 18 & 13.7 & - & - & - & - & - \\
\hline prec ARPAV 82 & apr $05-$ nov 18 & 13.7 & - & - & - & - & - \\
\hline prec ARPAV 83 & apr 05 - oct 18 & 13.6 & $\uparrow$ & - & - & - & $\downarrow$ \\
\hline prec ARPAV 110 & apr $05-$ nov 18 & 13.7 & - & - & $\downarrow$ & - & $\downarrow$ \\
\hline prec ARPAV 134 & apr $05-$ nov 18 & 13.7 & - & - & - & - & - \\
\hline prec ARPAV 137 & apr $05-$ nov 18 & 13.7 & - & - & - & - & - \\
\hline prec ARPAV 139 & apr $05-$ nov 18 & 13.7 & - & - & $\downarrow$ & - & - \\
\hline prec ARPAV 144 & apr $05-$ nov 18 & 13.7 & - & - & $\downarrow$ & - & - \\
\hline prec ARPAV 147 & apr $05-$ nov 18 & 13.7 & - & - & - & - & - \\
\hline prec ARPAV 148 & apr $05-$ nov 18 & 13.7 & - & - & - & - & - \\
\hline prec ARPAV 153 & apr 05 - jul 17 & 12.3 & - & - & - & - & - \\
\hline prec ARPAV 177 & apr $05-$ nov 18 & 13.7 & - & $\downarrow$ & - & - & $\downarrow$ \\
\hline prec ARPAV 232 & apr $05-$ nov 18 & 13.7 & - & - & - & - & - \\
\hline prec ARPAV 451 & apr $05-$ nov 18 & 13.7 & - & - & - & - & - \\
\hline idro Astico ARPAV 285 & apr $05-\operatorname{dec} 18$ & 13.8 & - & - & - & $\downarrow$ & $\downarrow$ \\
\hline idro Brenta ARPAV 283 & apr $05-\operatorname{dec} 18$ & 13.8 & - & - & - & - & $\downarrow$ \\
\hline idro Leogra CIN & apr $05-\operatorname{dec} 18$ & 13.8 & - & - & - & - & - \\
\hline
\end{tabular}
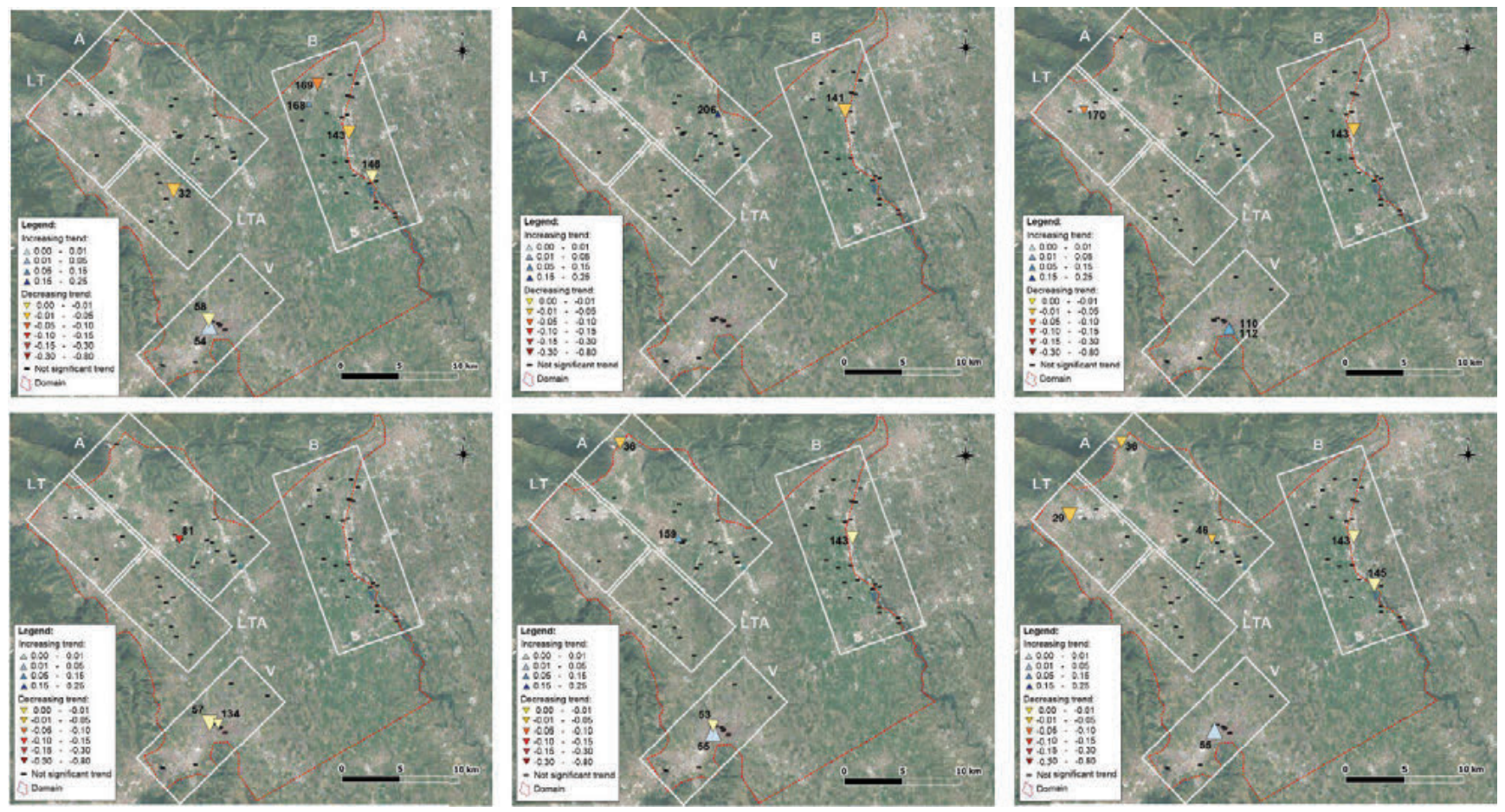

Fig. 6 - Statistically significant seasonal trends: from January to June. Gray rectangles subdivide the domain into five sectors depending on main likely hydraulic drivers. Black numbers show sensors ID.

Fig. 6 - Trend stagionali statisticamente significativi: da Gennaio a Giugno. I rettangoli grigi suddividono il dominio in cinque settori a seconda dei drivers idraulici. I numeri mostrano l'ID del punto di controllo. 

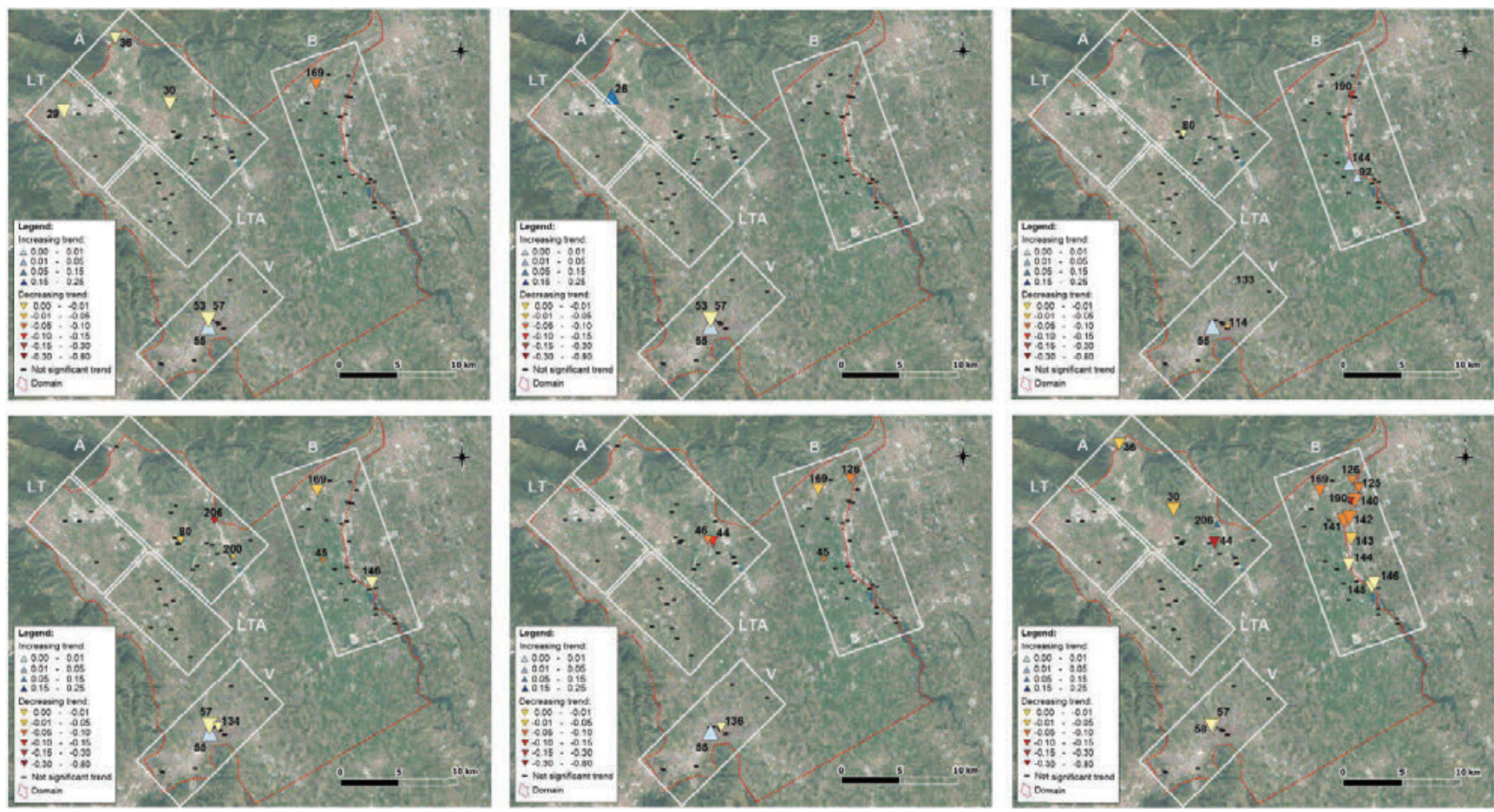

Fig. 7 - Statistically significant seasonal trends: from July to December. Gray rectangles subdivide the domain into five sectors depending on main likely hydraulic drivers. Black numbers show sensors ID.

Fig. 7 - Trend stagionali statisticamente significativi: da Luglio a Dicembre. I rettangoli grigi suddividono il dominio in cinque settori a seconda dei drivers idraulici. I numeri mostrano l'ID dei punti di controllo.

\section{Discussion}

This study applied the Mann-Kendall test and the Sen's slope estimator to analyse the available groundwater level dataset to identify statistically significant trends, assessing a general decreasing trend of the groundwater level within the domain roughly between 2005 and 2019 .

The two examples that show how these analyses depend on the selected period are worthy of remark because they highlight an important limitation, especially for the application of the MK test to this dataset, which is highly heterogeneous in terms of monitoring periods. The mentioned limitation could also explain the different results obtained in ARPAV (2016) for the periods 2000-2014 and 2005-2014. Indeed, for the second period considered by ARPAV (2016), it is evident in Figure 5 that the first years are exceptionally dry, whereas years 2011 and 2014 are particularly wet and characterised by extremely high groundwater levels. Thus, the results of the MK test and the Sen's slope estimator are reasonable for the period considered, but the discrepancy for the estimated trends depending on the considered time period undermines the reliability of the results when using trend testing to evaluate the quantitative status of the groundwater system, thus approximately evaluating if the exploitation is sustainable in the long term with this first basic approach (anthropogenic and climatic factors are not precisely assessed or differentiated here). There is no doubt about the robustness of the method applied but the question is how to obtain reliable results in assessing the sustainability of groundwater systems that slowly respond to human stresses and that are conditioned by periodic hydraulic cycles of different timescales.

The hypothesis is that the method in both the present study and ARPAV (2016) is applied to timeseries that are too short, and that are respectively in the downward and upward phase of a long hydraulic cycle. As a verification of such a thesis, the MK test and the Sen's slope estimator are applied to the longest available timeseries in the area. Altissimo et al. (1999) and Pettenuzzo [Università degli Studi di Padova, personal communication (1999)] made available several monthly timeseries starting from 1956 or 1960. Within the domain of interest, only one location of such timeseries is still measured by Sinergeo, which installed a sensor there to continuously record the groundwater level (sensor 27 in Marostica). Therefore, after a pre-processing of the available data, a monthly timeseries is now available from 1960 to 2020 with only $6 \%$ of missing values. After the MK test and the Sen's slope estimator are applied, the 60-year timeseries shows an overall significant decreasing trend of almost $10 \mathrm{~cm} /$ year. Observing the Marostica timeseries analysed in Figure 8, it is noticeable, however, that around 1990 there is a dramatic change in the decreasing slope. Before 1990, the estimated Sen's slope is $16 \mathrm{~cm} / \mathrm{year}$, while after 1990 the water table is still slightly decreasing but the trend is not statistically significant and the slope is much lower, $2 \mathrm{~cm} /$ year. This result clearly points to a strong depletion of the groundwater resource between 1960 and 1990, but a strong change afterwards: after 1990, the groundwater level seems to be much more stable. Without differentiating between anthropogenic and climatic conditions, the resource appears to be sustainably exploited in the long term. 


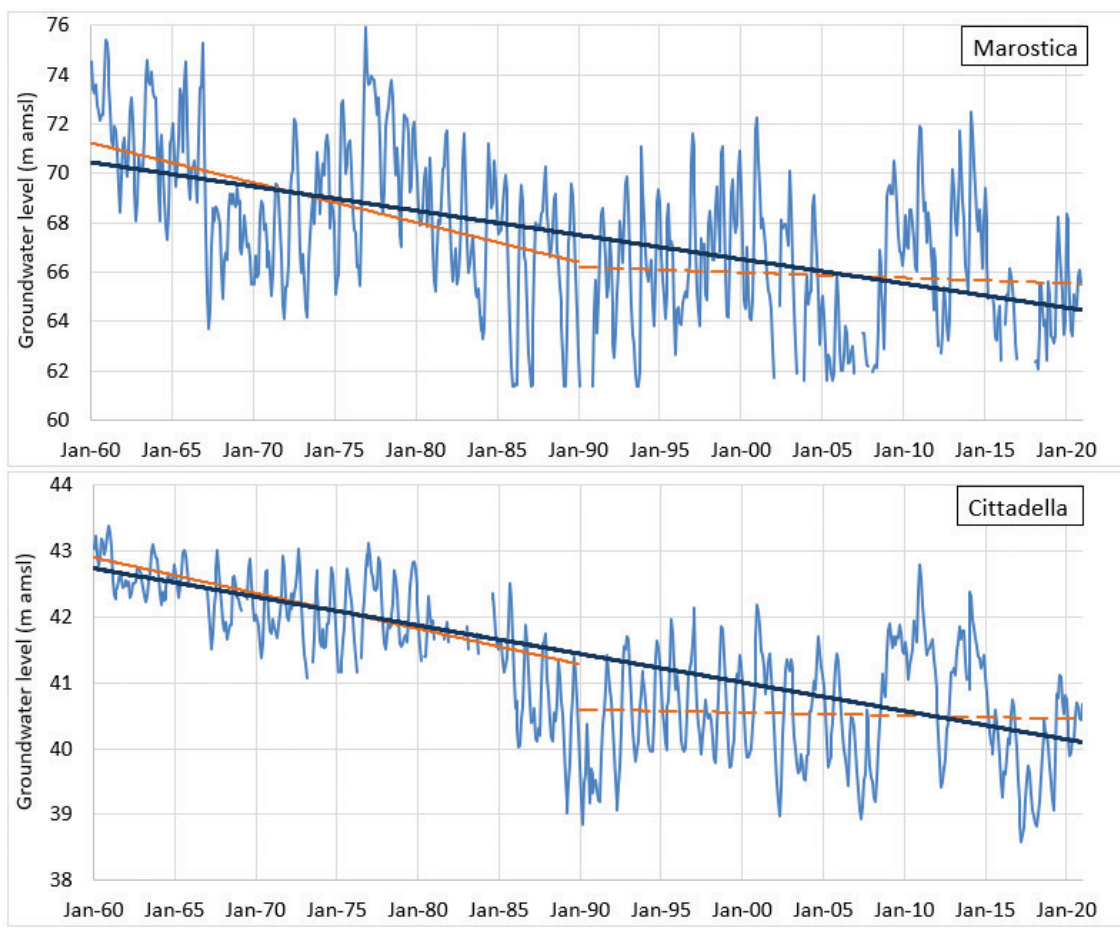

Fig. 8 - Trends for the two 60-years long groundwater level timeseries of Marostica and Cittadella. The dark blue line is the overall trend while the orange lines are the estimated trends for the two sub-timeseries. Trend lines are continuous if the trend has been evaluated as significant, dashed otherwise.

Fig. 8 - Trend delle due serie storiche del livello delle acque sotterranee di Marostica e Cittadella, lunghe 60 anni. La linea in blu scuro è la linea di tendenza dell'intera serie storica mentre le linee arancioni sono i trend stimati per le due distinte parti delle serie storiche originali. Le line di tendenza sono continue se il trend è stato valutato significativo, tratteggiate altrimenti.
Nevertheless, this is only the analysis of one timeseries, and a generalization to the whole domain is risky. Thus, as a further verification of such a trend, another long timeseries is considered: the groundwater level measured in Cittadella from 1956 to 2020 (Consorzio di Bonifica Brenta 2021). The location is just outside the basin investigated. It is located east of the Brenta river but only $15 \mathrm{~km}$ South-East of the Marostica control point (see Figure 1). The recorded groundwater level in Cittadella presents a smaller recorded range than the Marostica control point: $4.8 \mathrm{~m}$ versus $14.5 \mathrm{~m}$. The MK results are shown in Figure 8, and the trends change over time as the previous ones did: an overall significant decreasing trend of $4 \mathrm{~cm} /$ year, a stronger decrease between 1956 and 1990 with a slope of $5.5 \mathrm{~cm} /$ year, and a not statistically significant decreasing trend after 1990.

The two long timeseries are long enough to see the longterm trend of the groundwater level, diminishing the issue of the effect of the pluri-decadal hydraulic cycles. Nevertheless, there are only a few timeseries so long. Monitoring networks are usually relatively recent, having 10-15 working years. Therefore, another question arises: how long should a timeseries to be analysed with MK be, and which results can be considered reliable in a sustainability assessment? The answer depends on the investigated groundwater system but, if a long timeseries is available, this study suggests applying a Fourier analysis (Bras and Rodriguez-Iturbe 1994) to study the timeseries in the frequency domain. Indeed, the resulting power spectrum evaluates the signal energy entailed by each frequency and therefore points out the most significant periods of the timeseries, where the energy is highest. This analysis was carried out on the timeseries of the control point in Marostica. First, the timeseries was detrended by removing the linear trend calculated with the Sen's slope estimator and the few missing values were filled in with the cubic spline interpolator (De Boor 1978). Then, a Fourier analysis was applied to the complete detrended timeseries, the resulting power spectra is visible in Figure 9. From the power spectra, five main periodicities were evident: 6 months, corresponding to the seasonal oscillation; 1 year, corresponding to the annual oscillation; and three interannual oscillations, around 1.5 years, 5.5 years, and around 15 years. The last peak had the highest energy and there was not a single periodicity emerging, but periods of 10, 15, and 20 years, all having high energy and therefore highly characteristic of the timeseries. From these results, this study suggests having at least a 20year long timeseries to obtain reliable estimations of the overall trend on the Bacchiglione basin and to robustly assess the quantitative status of the groundwater system.

\section{Conclusions}

This study applied the Mann-Kendall test and the Sen's slope estimator as a robust and well-known method to assess the quantitative status of the groundwater system within the Bacchiglione basin and to estimate its quantitative sustainability in a first basic approach with no differentiation between anthropogenic and climatic drivers.

Previous literature found conflicting results for the investigated system, while this study identified generally decreasing trends between 2005 and 2019 by observing 79 timeseries. However, by applying such an analysis to the available heterogeneous dataset, the analysis was found to be sensible to the considered period. Even if this study reveals insight into the general decreasing trend within the domain, the results conflict with those of ARPAV (2016) that used 


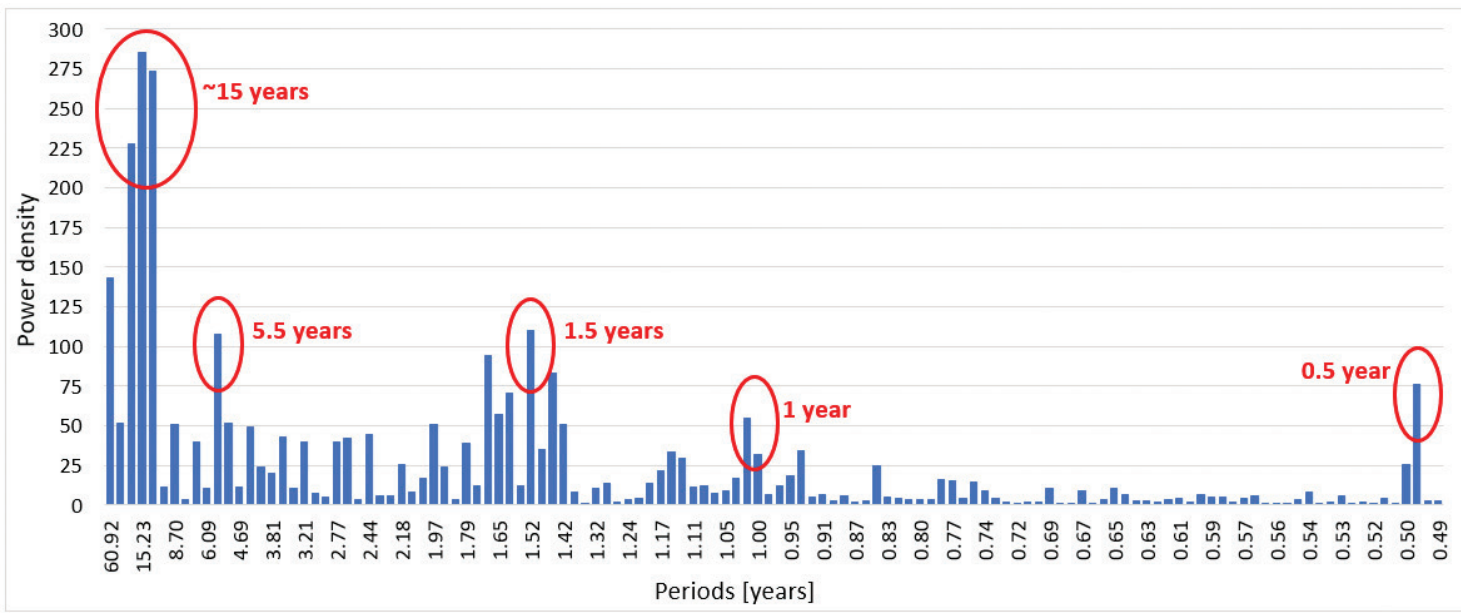

Fig. 9 - Power spectrum of the groundwater level timeseries in Marostica. Evaluated energy for each frequency $k$, reported as equivalent period $T=N / k$ where $N$ is the timeseries length. Fig. 9 - Spettro di potenza della serie storica del livello delle acque sotterranee di Marostica. L'energia è valutata per ogni frequenza k, riportata come l'equivalente periodo $\mathrm{T}=\mathrm{N} / \mathrm{k}$ dove $\mathrm{N}$ è la lunghezza della serie storica.

the same analysis but considered a slightly different period, 2000-2014. The reasons for such discrepancy were further investigated, and the assumption is that the results differ due to the analysis application to different periods of a long hydraulic cycle. Thus, to avoid such bias, two 60-year long timeseries are analysed using the same procedure. An overall decreasing trend is observed with a strong change in tendency around the year 1990. Even if an analysis based on two timeseries is only the first step and the results should be confirmed, the trend agreement here suggests the groundwater resource is being sustainably used. Even if the system has been highly deployed in the past and the groundwater level is not recovering towards the original levels, it is not decreasing significantly. Moreover, by carrying out a Fourier analysis on the timeseries of the control point in Marostica, several periodicities were identified, pinpointing multiple timescales of the hydraulic cycle. The longest periodicity is between 10 and 20 years. With this knowledge, this study suggests using the Mann-Kendall test and the Sen's slope estimator on longer timeseries to reduce the influence of long periodicities of the water cycle, thus obtaining more reliable results for the assessment of the quantitative status and for the related long-term sustainability of the groundwater system. This conclusion entails the necessity of having monitoring networks that have been active for several decades, which requires high operational effort but is essential (Heath 1976, WMO 1994; Van Lanen 1998).

\section{REFERENCES}

Aguilar JB, Orban P, Dassargues A, Brouyère S (2007) Identification of groundwater quality trends in a chalk aquifer threatened by intensive agriculture in Belgium. Hydrogeology Journal, 15, 1615.

Altissimo L, Dal Prà A, Scaltriti G (1999) Relazione conclusiva "Final report". Osservatorio interprovinciale per la tutela delle falde acquifere, Vicenza.

ARPAV (2016) Stato quantitativo dei corpi idrici sotterranei "Quantitative status of groundwater systems" - ALLEGATO A alla Dgr n. 552 del 26 aprile 2016. Regione del Veneto.

Bras LR, Rodriguez-Iturbe I (1994) Random functions and hydrology. Dover Publications, New York.

Consorzio di Bonifica Brenta (2021, febbraio 04) Dati Freatimetrici "Data of the groundwater level". Retrieved from Consorzio di Bonifica Brenta: http://www.pedemontanobrenta.it/dati_freatimetrici.asp

Dal Prà A, Bellatti R, Antonelli A, Costacurta R, Sbettega G (1977) Distribuzione dei materiali limoso-argillosi nel sottosuolo della pianura veneta "Distribution of silty-clayey materials in the subsoil of the Veneto plain". Quaderni IRSA e del Consiglio Nazionale delle Ricerche, IRSA, Rome.

Dal Prà A, Bellatti R, Costacurta R, Sbettega G (1976) Distribuzione delle ghiaie nel sottosuolo della pianura veneta "Distribution of gravel in the subsoil of the Veneto plain". Quaderni IRSA e del Consiglio Nazionale delle Ricerche, IRSA, Rome.

Daughney CJ, Reeves RR (2006) Analysis of temporal trends in New Zeland's groundwater quality based on data from the National Groundwater Monitoring Programme. Journal of Hydrology (New Zealand), 45, 41-62.

De Boor C (1978) A practical guide to splines. New York: SpringerVerlag.

Douglas EM, Vogel RM, Kroll CN (2000) Trends in floods and low flows in the United States: impact of spatial correlation. Journal of Hydrology, 240, 90-105.

Drápela K, Drápelová I (2011) Application of Mann-Kendall test and the Sen's slope estimates for trend detection in deposition data from Bilý Kř́̌ž (Beskydy Mts., the Czech Republic) 1997-2010. Beskydy, 4, 133-146.

Du Bui D, Kawamura A, Tong TN, Amaguchi H, Nakagawa N (2012) Spatio-temporal analysis of recent groundwater-level trends in the Red River Delta, Vietnam. Hydrogeology Journal, 20, 1635-1650.

Gan TY (1995) Trends in air temperature and precipitation for Canada and north-eastern USA. International Journal of Climatology, 15, $1115-1134$. 
Gavrilov MB, Lazić L, Pešic A, Milutinović M, Marković D, Stanković A, Gavrilov MM (2010) Influence of hail suppression on the hail trend in Serbia. Physical Geography, 31, 441-454.

Gavrilov MB, Tošić I, Marković SB, Unkašević M, Petrović P (2016) Analysis of annual and seasonal temperature trends using the Mann-Kendall test in Vojvodina, Serbia. Idöjárás, 120(2), 183-198.

Gocic M, Trajkovic S (2013) Analysis of changes in meteorological variables using Mann-Kendall and Sen's slope estimator statistical tests in Serbia. Global and Planetary Change, 100, 172-182.

Hamed KH (2008) Trend detection in hydrologic data: the MannKendall trend test under the scaling hypothesis. Journal of Hydrology, 349, 350-363.

Heath RC (1976) Design of Ground-Water Level Observation--Well Programs. Groundwater, 71-77.

Helsel DR, Hirsch RM (2002) Statistical methods in water resources (Vol. 323). US Geological Survey Reston, VA.

Hirsch RM, Slack JR, Smith RA (1982) Techniques of trend analysis for monthly water quality data. Water Resources Research, 18, $107-121$.

Hrnjak I, Lukić T, Gavrilov MB, Marković SB, Unkašević M, Tošić I (2014) Aridity in Vojvodina, Serbia. Theoretical and Applied Climatology, 115, 323-332.

Kahya E, Kalayc1 S (2004) Trend analysis of streamflow in Turkey. Journal of Hydrology, 289, 128-144.

Kendall MG (1948) Rank correlation methods. 4th Edition. Griffin, London.

Koutsoyiannis D (2003) Climate change, the Hurst phenomenon, and hydrological statistics. Hydrological Sciences Journal, 48, 3-24.

Mann HB (1945) Nonparametric tests against trend. Econometrica: Journal of the Econometric Society, 13, 245-259.

Mondal A, Kundu S, Mukhopadhyay A (2012) Rainfall trend analysis by Mann-Kendall test: A case study of north-eastern part of Cuttack district, Orissa. International Journal of Geology, Earth and Environmental Sciences, 2, 70-78.

Panda DK, Mishra A, Jena SK, James BK, Kumar A (2007) The influence of drought and anthropogenic effects on groundwater levels in Orissa, India. Journal of Hydrology, 343, 140-153.

Passadore G, Monego M, Altissimo L, Sottani A, Putti M, Rinaldo A (2012) Alternative conceptual models and the robustness of groundwater management scenarios in the multi-aquifer system of the Central Veneto Basin, Italy. Hydrogeology Journal, 20, 419-433.

Patle GT, Singh DK, Sarangi A, Rai A, Khanna M, Sahoo RN (2015) Time series analysis of groundwater levels and projection of future trend. Journal of the Geological Society of India, 85, 232-242.

Polemio M, Casarano D (2008) Climate change, drought and groundwater availability in southern Italy. Geological Society, London, Special Publications, 288, 39-51.

Rahman AU, Dawood M (2017) Spatio-statistical analysis of temperature fluctuation using Mann-Kendall and Sen's slope approach. Climate Dynamics, 48, 783-797.
Ribeiro L, Macedo ME (1995) Application of multivariate statistics, trend-and cluster analysis to groundwater quality in the Tejo and Sado aquifer. IAHS Publications-Series of Proceedings and Reports-Intern Assoc Hydrological Sciences, 225, 39-48.

Ribeiro L, Kretschmer N, Nascimento J, Buxo A, Rötting T, Soto G, Señoret M, Oyarzún J, Maturana M, Oyarzún R (2015) Evaluating piezometric trends using the Mann-Kendall test on the alluvial aquifers of the Elqui River basin, Chile. Hydrological Sciences Journal, 60, 1840-1852.

Sen PK (1968) Estimates of the regression coefficient based on Kendall's tau. Journal of the American Statistical Association, 63, 1379-1389.

Shadmani M, Marofi S, Roknian M (2012) Trend analysis in reference evapotranspiration using Mann-Kendall and Spearman's Rho tests in arid regions of Iran. Water Resources Management, 26, 211-224.

Some'e BS, Ezani A, Tabari H (2013) Spatiotemporal trends of aridity index in arid and semi-arid regions of Iran. Theoretical and Applied Climatology, 111, 149-160.

Svensson C, Kundzewicz WZ, Maurer T (2005) Trend detection in river flow series: 2. Flood and low-flow index series/Détection de tendance dans des séries de débit fluvial: 2. Séries d'indices de crue et d'étiage. Hydrological Sciences Journal, 50, 811-824.

Tabari H, Marofi S, Aeini A, Talaee PH, Mohammadi K (2011) Trend analysis of reference evapotranspiration in the western half of Iran. Agricultural and Forest Meteorology, 151, 128-136.

Tabari H, Nikbakht J, Some'e BS (2012) Investigation of groundwater level fluctuations in the north of Iran. Environmental Earth Sciences, 66, 231-243.

Van Lanen HA (1998) Monitoring for groundwater management in (semi)-arid regions. Unesco.

Vousoughi FD, Dinpashoh Y, Aalami MT, Jhajharia D (2013) Trend analysis of groundwater using non-parametric methods (case study: Ardabil plain). Stochastic Environmental Research and Risk Assessment, 27, 547-559.

Wahlin K, Grimvall A (2010) Roadmap for assessing regional trends in groundwater quality. Environmental Monitoring and Assessment, $165,217-231$

Waldner P, Marchetto A, Thimonier A, Schmitt M, Rogora M, Granke O, et al. (2014) Detection of temporal trends in atmospheric deposition of inorganic nitrogen and sulphate to forests in Europe. Atmospheric Environment, 95, 363-374.

Wibig J, Glowicki B (2002) Trends of minimum and maximum temperature in Poland. Climate Research, 20, 123-133.

WMO (1994) Guide to Hydrological Practices (WMO-No.168). World Meteorological Organization, Geneva.

Yue S, Pilon P, Cavadias G (2002) Power of the Mann-Kendall and Spearman's rho tests for detecting monotonic trends in hydrological series. Journal of Hydrology, 259, 254-271.

Zhang Q, Xu CY, Zhang Z (2009) Observed changes of drought/wetness episodes in the Pearl River basin, China, using the standardized precipitation index and aridity index. Theoretical and Applied Climatology, 98, 89-99. 